\title{
Simultaneous Spectrophotometric Determination of Nitrite and Nitrate by Flow Injection Analysis
}

\author{
Ali Asghar Ensafi, ${ }^{\dagger}$ Behzad RezaeI, and Siyavah Nouroozi \\ College of Chemistry, Isfahan University of Technology, Isfahan, 84156, Iran
}

\begin{abstract}
A new catalytic spectrophotometric method is reported for the simultaneous determination of nitrite and nitrate by flow injection analysis, based on the catalytic effect of nitrite on the redox reaction between pyrogallolsulfonephthalein and potassium bromate in acidic media. Nitrate can also be on-line reduced to nitrite with a modified copper-coated cadmium reduction column. The reaction was monitored spectrophotometrically by measuring the decrease in the absorbance of pyrogallolsulfonephthalein at $465 \mathrm{~nm}$. Various analytical parameters such as effects of acidity, reagent concentrations, flow rates, sample sizes, lengths of the reaction coil and temperatures were studied and were optimized. Under the optimized conditions, the calibration graph was linear for 2.4 to $160 \mathrm{ng} \mathrm{ml}^{-1}$ of nitrite and 4.0 to $100 \mathrm{ng} \mathrm{ml}^{-1}$ of nitrate. The influences of potential interfering cations and anions for nitrite and nitrate determination were studied. The method is successfully applied for food and water samples. Up to ten samples can be analyzed per hour.
\end{abstract}

(Received January 23, 2004; Accepted August 6, 2004)

Nitrites and nitrates are commonly monitored for environmental protection purposes in water, agriculture and food control. Nitrite produces carcinogenic nitrosamines in the human body through its reactions with amines or amides. ${ }^{1}$ Therefore, simultaneous determination of nitrite and nitrate is of great importance. Most of the simultaneous determinations of nitrite and nitrate are based on the reduction of nitrate to nitrite, followed by spectrophotometric determination of initial and produced nitrite. The concept of flow injection analysis has been applied successfully to the simultaneous determination of nitrite and nitrate, using various techniques. ${ }^{2-9}$

In the most of the procedures, nitrate is reduced to nitrite with a copperized cadmium column. Most of these methods adopted the above-mentioned diazo coupling reaction except for Refs. 8 and 9. Such methods have the disadvantage of toxicity of the reagents used, and insufficient sensitivity, and they suffer from several interfering ions.

In this paper, a new flow injection spectrophotometric method is proposed for simultaneous determination of nitrite and nitrate based on the catalytic effect of nitrite on the oxidation of pyrogallolsulfonephthalein with bromate in acidic media. The proposed method was used to the determination of nitrite and nitrate in real samples with satisfactory results.

\section{Experimental}

\section{Apparatus}

A diagram of the flow system employed is shown in Fig. 1. The decrease in absorbance was measured with a Shimadzu Model $6 \mathrm{AV}$ spectrophotometer equipped with a flow through cell $(20 \mu \mathrm{l}$ inner volume) of $1.0 \mathrm{~cm}$ optical path, whose output was connected to a Shimadzu signal processing instrument

\footnotetext{
† To whom correspondence should be addressed.

E-mail: Ensafi@cc.iut.ac.ir
}

(Model C-R4AX Chromatopac). A 12-channel peristaltic pump (Desaga, Model PLG) with three silicon rubber tubes $(1.0 \mathrm{~mm}$ i.d.) was used. PTFE mixing joints and PTFE tubing $(1.0 \mathrm{~mm}$ i.d.) were used for the connections and for the reaction coil. The controlled water bath (Gallen-Kamp, BLG, $220 \mathrm{~V}$ ) was used at a given temperature of $30 \pm 0.1{ }^{\circ} \mathrm{C}$. Sample solutions were injected using a six position rotary Supelco valve with a sample loop that contained a $60 \mathrm{~cm}$ PTFE tubing $(1.0 \mathrm{~mm}$ i.d.) and a reduction column $(7.5 \mathrm{~cm}$ with $3.0 \mathrm{~mm}$ i.d. made of PMMA) (Fig. 2).

\section{Reagents and chemicals}

All the solutions were prepared using reagent grade chemicals. Doubly distilled water was used throughout.

Nitrite standard solution $\left(1000 \mu \mathrm{g} \mathrm{ml}^{-1}\right)$ was prepared by dissolving $0.1499 \mathrm{~g}$ of dried (for $4 \mathrm{~h}$ at $105-110^{\circ} \mathrm{C}$ ) sodium nitrite (Merck) in doubly distilled water and diluting to $100 \mathrm{ml}$ in a volumetric flask. A pellet of sodium hydroxide was added to prevent liberation of nitrous acid and $1 \mathrm{ml}$ of chloroform was added to inhibit bacterial growth. Each working standard

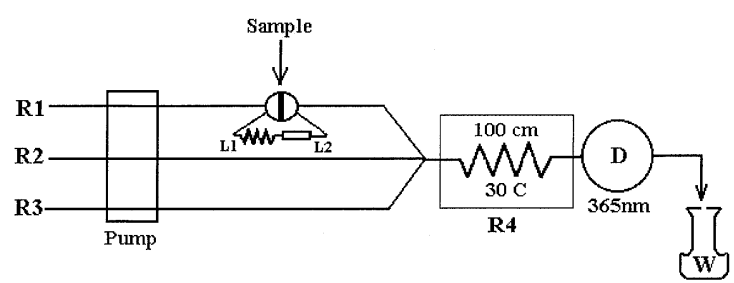

Fig. 1 Schematic representation of the FI manifold employed for the simultaneous determination of nitrite and nitrate: $R_{1}$, carrier; $R_{2}$, bromate solution; $\mathrm{R}_{3}$, a mixture solution of the dye, sulfuric acid plus potassium sulfate; $\mathrm{R}_{4}$, reaction coil; $\mathrm{L}_{1}$, injection loop; $\mathrm{L}_{2}$, reduction column; D, detector; W, waste. 


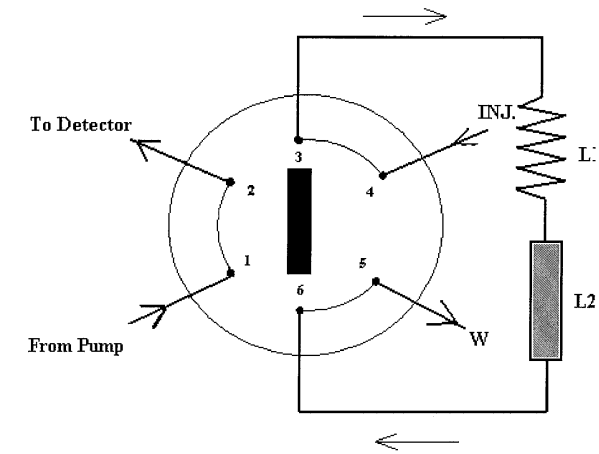

A: Loading

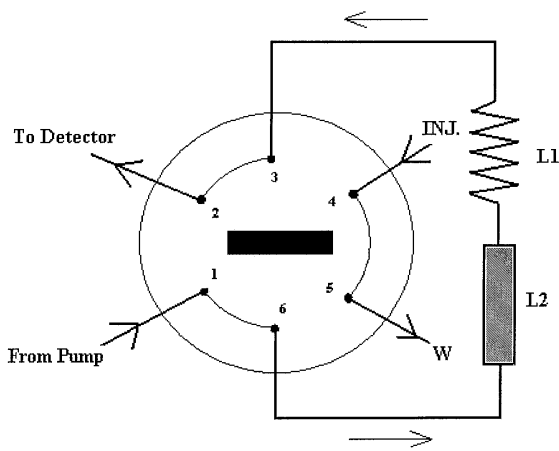

B: Injection

Fig. 2 Schematic representation of injection valve operation at: A) loading, and B) injection mode.

solution was freshly prepared by diluting the stock solution with water.

A nitrate standard solution $\left(1000 \mu \mathrm{g} \mathrm{ml}^{-1}\right)$ was prepared by dissolving $0.1371 \mathrm{~g}$ of dried (for $4 \mathrm{~h}$ at $105-110^{\circ} \mathrm{C}$ ) sodium nitrate (Merck) in doubly distilled water and diluting to $100 \mathrm{ml}$ in a volumetric flask. The solution was treated with a few drops of chloroform and kept in a refrigerator for preservation.

A sodium bromate solution $(0.20 \mathrm{M})$ was prepared by dissolving $1.509 \mathrm{~g}$ of $\mathrm{NaBrO}_{3}$ (Merck) in water and diluting to $50 \mathrm{ml}$ in a volumetric flask.

A potassium sulfate solution $(1.0 \mathrm{M})$ was prepared by dissolving $17.425 \mathrm{~g}$ of $\mathrm{K}_{2} \mathrm{SO}_{4}$ (Merck) in water and diluting to $100 \mathrm{ml}$ in a volumetric flask.

A pyrogallolsulfonephthalein solution $\left(2.65 \times 10^{-4} \mathrm{M}\right)$ was prepared by dissolving $0.025 \mathrm{~g}$ of the dye (Merck) in $100 \mathrm{ml}$ of distilled water then $50 \mathrm{ml}$ of ethanol was added step by step until the dye dissolved completely. Then the resulting solution was diluted with water in a $250-\mathrm{ml}$ volumetric flask.

Sulfuric acid stock solution $(1.0 \mathrm{M})$ was prepared by diluting $13.9 \mathrm{ml}$ of concentrated solution $(96 \%)$ in a $250-\mathrm{ml}$ volumetric flask with doubly distilled water.

\section{Reduction column preparation}

The reduction column ( $\mathrm{L}_{2}$ in Fig. 2) was made from a piece of PMMA tube $(7.5 \mathrm{~cm} \times 3 \mathrm{~mm}$ i.d.) and was filled with copperized-cadmium granules (Merck) of diameter $420 \mu \mathrm{m}$ held in a position with glass wool plugs. The column filled with cadmium granules was washed with distilled water carefully (for $2 \mathrm{~h}$ ) and then washed with a solution of hydrochloric acid $(1.0 \mathrm{M})$ for $2 \mathrm{~h}$ on line and again washed with distilled water. After that, the column was coated with copper by pumping a solution of $1 \%(\mathrm{w} / \mathrm{v})$ copper sulfate through the column. The reduction column was regenerated by passing the copper sulfate solution (in place of water) for $10 \mathrm{~min}$.

\section{Recommended procedure}

As shown in Fig. 1, each solution containing carrier $\left(\mathrm{H}_{2} \mathrm{O}\right.$, $\left(\mathrm{R}_{1}\right)$ ), bromate solution $\left(\mathrm{R}_{2}\right)$, and a mixture of the dye plus sulfuric acid and potassium sulfate $\left(\mathrm{R}_{3}\right)$ previously thermostated at an appropriate temperature $\left(30^{\circ} \mathrm{C}\right)$ is pumped at $13.5 \mathrm{ml} \mathrm{h}^{-1}$ (for each channel) via a peristaltic pump. The standard solution containing 2.4-160.0 $\mathrm{ng} \mathrm{ml}^{-1} \mathrm{NO}_{2}^{-}$and $4.0-100.0 \mathrm{ng} \mathrm{ml}^{-1}$ $\mathrm{NO}_{3}{ }^{-}$was injected into the carrier stream via a sample injection valve. The sample solution was divided into two parts. The first part was directly treated with a mixture of bromate, sulfuric acid and the dye, and then passed to the sample flow cell of the spectrophotometer, where the decrease in absorbance at $465 \mathrm{~nm}$ was measured as initial nitrite concentration (first shoulder peak). The second part of the injected sample solution was treated with a mixture of bromate, sulfuric acid and the dye after being treated with the reduction column $\left(\mathrm{L}_{2}\right)$ at the injection loop and then passed to the sample flow cell of the spectrophotometer, where the decrease in absorbance at $465 \mathrm{~nm}$ was measured and related to the total concentration of nitrite and nitrate (second peak). Thus, the nitrate content was determined by the difference. The concentrations of nitrite and nitrate were evaluated from the peak height measurements by using a calibration curve prepared from the results obtained on standards.

\section{Real sample analysis}

For the beef sausage, $5.0 \mathrm{~g}$ of sample was mixed and homogenized in a mortar. The thoroughly mixed sample was taken in a $500 \mathrm{ml}$ beaker and digested carefully by heating of solution content in water for $2 \mathrm{~h}$. The mixture was filtered using filter paper (Whatman No. 1). The resulting solution was collected in a $100 \mathrm{ml}$ volumetric flask and diluted with water to the mark. The nitrate and nitrite contents were measured by a procedure following the method recommended by the AOAC. ${ }^{10}$ The river water sample passed through a piece of filter paper (Whatman No. 1). Each of the sample solutions of sausage and river water passed through a column $(10 \times 1.0 \mathrm{~cm})$ containing cation exchange resin before analysis. Tap water sample was used without any pretreatment.

\section{Results and Discussion}

\section{System optimization}

In this paper we introduce a new manifold configuration for simultaneous determination of nitrite and nitrate. In the new manifold, we inserted the reducing column plus a column containing cation exchange resin directly after the sample loop in the injection port. This new manifold increases the selectivity of the method compared to those of other existing methods for nitrite-nitrate determination. Pyrogallolsulfonephthalein is a dye can be oxidized with a strong oxidizing agent such as bromate in slow rate. The oxidation reaction of pyrogallolsulfonephthalein occurs quickly in the presence of trace amounts of nitrite, because nitrite acts as a suitable catalytic agent in the oxidation of many organic compounds in acidic media when bromate is used as an oxidation agent. ${ }^{11}$ Pyrogallolsulfonephthalein undergoes rapid oxidation in the presence of bromate in acidic media when nitrite is added at trace level, and the absorbance of the dye decreases rapidly at $465 \mathrm{~nm}$. Therefore, $465 \mathrm{~nm}$ was used as the detection wavelength. In addition, nitrate does not affect directly the oxidation reaction rate (even in the presence of 


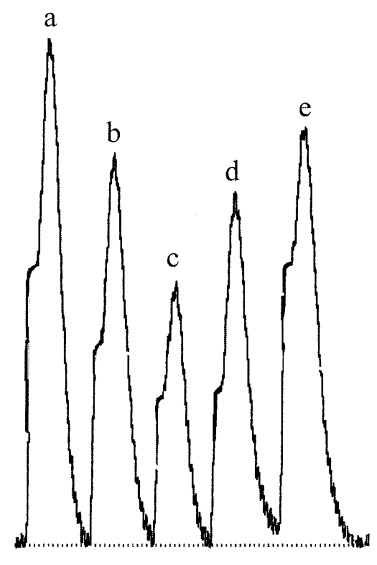

Table 1 Effect of foreign ions on the determination of nitrite and nitrate

\begin{tabular}{lc}
\hline \multicolumn{1}{c}{ Species } & Tolerance limit $\left(W_{\text {Ion }} / W_{\text {nitrite }}\right)$ \\
\hline $\mathrm{Cr}^{3+}, \mathrm{Mg}^{2+}, \mathrm{Ni}^{2+}, \mathrm{Zn}^{2+}, \mathrm{Mn}^{2+}, \mathrm{Cs}^{+}, \mathrm{Co}^{2+}$, & 2500 \\
$\mathrm{~Pb}^{2+}, \mathrm{Sn}^{2+}, \mathrm{Cd}^{2+}, \mathrm{S}_{2} \mathrm{O}_{6}{ }^{2-}, \mathrm{HCO}_{3}^{-}$, & \\
$\mathrm{CH}_{3} \mathrm{COO}^{-}, \mathrm{SO}_{3}^{2-}, \mathrm{F}^{-}, \mathrm{ClO}_{3}-$ & \\
$\mathrm{Cu}^{2+}$ & 300 \\
$\mathrm{NH}_{4}^{+}, \mathrm{Hg}^{2+}$ & 200 \\
$\mathrm{Fe}^{3+}$ & 125 \\
$\mathrm{Ag}^{+}$ & 100 \\
$\mathrm{Fe}^{2+}$ & 50 \\
$\mathrm{IO}_{4}$ & 40 \\
\hline
\end{tabular}

Fig. 3 A typical flow-injection signal for simultaneous determination of nitrite and nitrate at the optimum conditions. a) $0.080 \mu \mathrm{g} \mathrm{ml}^{-1} \mathrm{NO}_{2}^{-}, 0.080 \mu \mathrm{g} \mathrm{ml}^{-1} \mathrm{NO}_{3}^{-}$; b) $0.060 \mu \mathrm{g} \mathrm{ml}^{-1} \mathrm{NO}_{2}^{-}$, $0.060 \mu \mathrm{g} \mathrm{ml}^{-1} \mathrm{NO}_{3}^{-}$; c) $0.040 \mu \mathrm{g} \mathrm{ml}^{-1} \mathrm{NO}_{2}^{-}, 0.040 \mu \mathrm{g} \mathrm{ml}^{-1} \mathrm{NO}_{3}^{-} ; \mathrm{d}$ ) $0.040 \mu \mathrm{g} \mathrm{ml}^{-1} \mathrm{NO}_{2}^{-}, 0.060 \mu \mathrm{g} \mathrm{ml}^{-1} \mathrm{NO}_{3}^{-}$; e) $0.080 \mu \mathrm{g} \mathrm{ml}^{-1} \mathrm{NO}_{2}^{-}$, $0.040 \mu \mathrm{g} \mathrm{ml}^{-1} \mathrm{NO}_{3}{ }^{-}$.

1000-fold relation to nitrite). Preliminary tests were carried out with the aid of different flow assemblies to select optimal manifold configurations. The assembly in Fig. 1 was selected as the one producing the best compromise between peak height and the shape of the peak. In order to optimize the flow injection system, we studied the influence of the reagent concentrations and the temperature as well as other variables on the sensitivity and peak selectivity (for nitrite and nitrate determination).

Experimental results showed that the reaction could run faster in sulfuric acid media than other acids such as $\mathrm{HCl}, \mathrm{HNO}_{3}$ and $\mathrm{H}_{3} \mathrm{PO}_{4}$ in the same concentration. Therefore, we selected sulfuric acid for the study. The influence of reagent concentrations and temperature on the sensitivity was checked using $0.080 \mu \mathrm{g} \mathrm{ml}^{-1}$ nitrite and nitrate, pump flow rate of 15.2 $\mathrm{ml} \mathrm{h}^{-1}$, sample loop volume of $200 \mu \mathrm{l}$ and reaction coil length of $150 \mathrm{~cm}$ at room temperature.

The influence of sulfuric acid concentration on the sensitivity was studied in the range of 0.04 to $0.24 \mathrm{M}$, with $0.080 \mu \mathrm{g} \mathrm{ml}^{-1}$ nitrite at $25^{\circ} \mathrm{C}$. The results showed that increasing the acid concentration causes increase in sensitivity up to $0.20 \mathrm{M}$, whereas higher concentration does not affect the sensitivity. Therefore, $0.20 \mathrm{M}$ sulfuric acid concentration was selected.

The influence of the dye concentration on the peak height was studied for the range of $2.12 \times 10^{-5}$ to $1.06 \times 10^{-4} \mathrm{M}$, with 0.20 $\mathrm{M}$ sulfuric acid and $0.080 \mu \mathrm{g} \mathrm{ml}^{-1}$ of nitrite at $25^{\circ} \mathrm{C}$. The results showed that increasing the dye concentration up to $6.36 \times 10^{-5}$ $M$ causes increases in the sensitivity. Higher concentrations of the dye cause decreasing sensitivity. This may be due to the change in molar absorptivity of the solution. Therefore $4.24 \times$ $10^{-5} \mathrm{M}$ was used for further study.

The effect of bromate concentration on the sensitivity was studied for the range of $8.0 \times 10^{-3}$ to $4.0 \times 10^{-2} \mathrm{M}$, with $4.24 \times$ $10^{-5} \mathrm{M}$ of the dye, $0.20 \mathrm{M} \mathrm{H}_{2} \mathrm{SO}_{4}$ and $0.080 \mu \mathrm{g} \mathrm{ml}^{-1}$ of nitrite at $25^{\circ} \mathrm{C}$. The results showed that the peak height increased with increasing bromate concentration up to $0.032 \mathrm{M}$, and then leveled off. Therefore, $0.040 \mathrm{M}$ bromate concentration was selected.

The influence of temperature on the peak height was studied in the range of 25 to $40^{\circ} \mathrm{C}$ in the presence of the optimum reagent concentrations and $0.080 \mu \mathrm{g} \mathrm{ml}^{-1} \mathrm{NO}_{2}{ }^{-}$. The results showed that with increasing temperature, the sensitivity decreased. This is due to the fact that, if the temperature increases, the uncatalyzed reaction goes to a faster rate than the rate for the catalyzed reaction. Therefore, $30^{\circ} \mathrm{C}$ was selected, due to simplicity.

The influence of manifold variables on the sensitivity (such as pump flow rate, length of the reaction coil, and sample loop volume) were studied with the optimized reagents concentration and $0.080 \mu \mathrm{g} \mathrm{ml}^{-1} \mathrm{NO}_{2}^{-}$at $30^{\circ} \mathrm{C}$. The peak height depends on the residence time of the sample zone in the system; e.g. on the total flow rate and the length of the reaction coil. The effect of the flow rate was checked over the range $10-36 \mathrm{ml} \mathrm{h}^{-1}$ for each channel. The results showed that, as the flow rate increased, the signal was decreased. This is due to the fact that, at higher flow rates, the residence time of the mixture of the reagent is decreased and thus the consumption of the dye decreased, causing a decrease in the peak height. From these results, a pump flow rate of $15 \mathrm{ml} \mathrm{h}^{-1}$ (for each channel) was selected for study.

The influence of length of the reaction coil length on the sensitivity was studied with flow rate of $15 \mathrm{ml} \mathrm{h}^{-1}$ (for each channel). The results showed that increasing the length of the reaction coil from 50 to $250 \mathrm{~cm}$ first causes increasing in the signal sensitivity (up to $100 \mathrm{~cm}$ ), and then the sensitivity decreased (for $>100 \mathrm{~cm}$ ). As the length of the reaction coil increased, the rate of uncatalyzed reaction increased faster than the rate for the catalyzed reaction. Therefore, a $100 \mathrm{~cm}$ length was chosen as the optimum length of the reaction coil.

The sample volume injected into the carrier line has a significant effect on the peak height. The signal increases with increasing sample volume up to $230 \mu \mathrm{l}$ and then remains nearly constant for larger volumes up to $300 \mu \mathrm{l}$. In addition, using a sample volume larger than $145 \mu \mathrm{l}$ cause peak broadening and tailing. Therefore, a sample volume of $145 \mu \mathrm{l}$ was chosen for further experiments because of the sharper peaks.

The optimum length of the reduction column was established with $0.080 \mu \mathrm{g} \mathrm{ml}^{-1}$ nitrate by using the copperized-cadmium column length of 2.5 to $10 \mathrm{~cm}$. For each situation, the percentage reduction of nitrate to nitrite was determined by comparing of the plateau achieved with that corresponding to $0.080 \mu \mathrm{g} \mathrm{ml}^{-1}$ nitrite solution processed in the same way. A column length of $7.5 \mathrm{~cm}$ was selected, because the reduction was completed and reproducible, while the backpressure was comparatively low.

The length of the injection coil ( $\mathrm{L}_{1}$ in Fig. 2) for obtaining a shoulder-shaped peak is critical. So, the influence of $\mathrm{L}_{1}$ for obtaining a shoulder-shaped peak signal for the two analytes was studied in the range of 25 to $75 \mathrm{~cm}$. The results showed 
Table 2 Determination of nitrite and nitrate in river water (Zayandeh Roud river in Isfahan City)

\begin{tabular}{|c|c|c|c|c|c|c|c|c|c|c|}
\hline \multirow{3}{*}{$\begin{array}{c}\text { Sample } \\
\text { No. }\end{array}$} & \multicolumn{5}{|c|}{ Nitrite } & \multicolumn{5}{|c|}{ Nitrate } \\
\hline & \multirow{2}{*}{$\begin{array}{l}\text { Added/ } \\
\mu \mathrm{g} \mathrm{ml}^{-1}\end{array}$} & \multicolumn{2}{|c|}{ Found/ $\mu \mathrm{g} \mathrm{ml}^{-1}$} & \multicolumn{2}{|c|}{ Recovery, \% } & \multirow{2}{*}{$\begin{array}{l}\text { Added/ } \\
\mu \mathrm{g} \mathrm{ml}^{-1}\end{array}$} & \multicolumn{2}{|c|}{ Found $/ \mu \mathrm{g} \mathrm{ml}^{-1}$} & \multicolumn{2}{|c|}{ Recovery, $\%$} \\
\hline & & FIA & Standard & FIA & Standard & & FIA & Standard & FIA & Standard \\
\hline 1 & 0.000 & $1.5 \times 10^{-4}$ & $1.2 \times 10^{-4}$ & - & - & 0.000 & $6.7 \times 10^{-3}$ & $2.5 \times 10^{-3}$ & - & - \\
\hline 2 & 0.040 & 0.0392 & 0.0398 & 98 & 100 & 0.040 & 0.0413 & 0.0385 & 103 & 96 \\
\hline 3 & 0.060 & 0.0615 & 0.0602 & 102 & 100 & 0.060 & 0.065 & 0.0595 & 108 & 99 \\
\hline 4 & 0.080 & 0.0783 & 0.0806 & 98 & 101 & 0.080 & 0.0808 & 0.0797 & 101 & 99.5 \\
\hline 5 & 0.100 & 0.1006 & 0.0994 & 100 & 99.5 & 0.100 & 0.095 & 0.101 & 95 & 101 \\
\hline
\end{tabular}

Table 3 Determination of nitrite and nitrate in tap water (Isfahan City)

\begin{tabular}{|c|c|c|c|c|c|c|c|c|c|c|}
\hline \multirow{3}{*}{$\begin{array}{c}\text { Sample } \\
\text { No. }\end{array}$} & \multicolumn{5}{|c|}{ Nitrite } & \multicolumn{5}{|c|}{ Nitrate } \\
\hline & \multirow{2}{*}{$\begin{array}{l}\text { Added/ } \\
\mu \mathrm{g} \mathrm{ml}^{-1}\end{array}$} & \multicolumn{2}{|c|}{ Found $/ \mu \mathrm{g} \mathrm{ml}^{-1}$} & \multicolumn{2}{|c|}{ Recovery, \% } & \multirow{2}{*}{$\begin{array}{l}\text { Added/ } \\
\mu \mathrm{g} \mathrm{ml}^{-1}\end{array}$} & \multicolumn{2}{|c|}{ Found/ $\mu \mathrm{g} \mathrm{ml}^{-1}$} & \multicolumn{2}{|c|}{ Recovery, \% } \\
\hline & & FIA & Standard & FIA & Standard & & FIA & Standard & FIA & Standard \\
\hline 1 & 0.000 & $4 \times 10^{-3}$ & $6 \times 10^{-4}$ & - & - & 0.000 & $5 \times 10^{-3}$ & $4 \times 10^{-3}$ & - & - \\
\hline 2 & 0.040 & 0.0397 & 0.04 & 92 & 100 & 0.040 & 0.0393 & 0.04 & 98 & 100 \\
\hline 3 & 0.060 & 0.0567 & 0.059 & 94 & 99 & 0.060 & 0.0599 & 0.0593 & 100 & 99 \\
\hline 4 & 0.080 & 0.0776 & 0.078 & 97 & 98 & 0.080 & 0.0809 & 0.0785 & 101 & 98 \\
\hline 5 & 0.100 & 0.105 & 0.101 & 105 & 101 & 0.100 & 0.096 & 0.101 & 96 & 101 \\
\hline
\end{tabular}

Table 4 Determination of nitrite and nitrate in sausage samples

\begin{tabular}{|c|c|c|c|c|c|c|c|c|c|c|}
\hline \multirow{3}{*}{$\begin{array}{c}\text { Sample } \\
\text { No. }\end{array}$} & \multicolumn{5}{|c|}{ Nitrite } & \multicolumn{5}{|c|}{ Nitrate } \\
\hline & \multirow{2}{*}{$\begin{array}{l}\text { Added/ } \\
\mu \mathrm{g} \mathrm{ml}^{-1}\end{array}$} & \multicolumn{2}{|c|}{ Found $/ \mu \mathrm{g} \mathrm{ml}^{-1}$} & \multicolumn{2}{|c|}{ Recovery, \% } & \multirow{2}{*}{$\begin{array}{l}\text { Added/ } \\
\mu \mathrm{g} \mathrm{ml}^{-1}\end{array}$} & \multicolumn{2}{|c|}{ Found/ $\mu \mathrm{g} \mathrm{ml}^{-1}$} & \multicolumn{2}{|c|}{ Recovery, \% } \\
\hline & & FIA & Standard & FIA & Standard & & FIA & Standard & FIA & Standard \\
\hline 1 & 0.000 & $3 \times 10^{-3}$ & $3 \times 10^{-4}$ & - & - & 0.000 & $8 \times 10^{-3}$ & $5 \times 10^{-4}$ & - & - \\
\hline 2 & 0.040 & 0.037 & 0.0405 & 94 & 101 & 0.040 & 0.0441 & 0.0405 & 110 & 101 \\
\hline 3 & 0.060 & 0.055 & 0.0601 & 92 & 100 & 0.060 & 0.0625 & 0.0604 & 104 & 100.5 \\
\hline 4 & 0.080 & 0.0803 & 0.0799 & 100 & 100 & 0.080 & 0.0777 & 0.0798 & 97 & 100 \\
\hline 5 & 0.100 & 0.103 & 0.0997 & 103 & 100 & 0.100 & 0.0981 & 0.0998 & 98 & 100 \\
\hline
\end{tabular}

that when the coil length was $60 \mathrm{~cm}$, a shoulder-shaped signal consisting of the two peaks (the first corresponding to the nitrite content and the second to the sum of nitrite and nitrate) was obtained. At coil lengths shorter than $55 \mathrm{~cm}$, the peak shoulder disappeared.

\section{Analytical parameters}

A typical flow injected signal is shown in Fig. 3. Under the optimized conditions and at $30^{\circ} \mathrm{C}$, the peak height obtained with nitrite and nitrate was proportional to the concentration of nitrite and nitrate for the range of 2.4 to $160 \mathrm{ng} \mathrm{ml}^{-1}$ and 4 to $100 \mathrm{ng}$ $\mathrm{ml}^{-1}$, respectively. The detection limits for nitrite were $1.6 \mathrm{ng}$ $\mathrm{ml}^{-1}$ and for nitrate were $3.0 \mathrm{ng} \mathrm{ml}^{-1}(S / N=3)$. The relative standard deviation $(n=10)$ was $2.8 \%$ and $3.7 \%$ at $0.080 \mu \mathrm{g} \mathrm{ml}^{-1}$ nitrite and nitrate, respectively.

\section{Interference studies}

Under the optimized conditions, the influence of several cations and anions on the determination of $0.080 \mu \mathrm{g} \mathrm{ml}^{-1}$ nitrite or nitrate was studied. The tolerance limit was defined as the value at which interference ions cause less than $\pm 3 \%$ relative error for the nitrite determination. The results are summarized in Table 1. The results show good selectivity of the method for simultaneous determination of nitrite and nitrate.

\section{Applications in real samples}

The present method was successfully applied to the simultaneous determination of nitrite and nitrate in a number of river water, tap water and sausage samples. In view of the unknown composition of the samples, equivalent portions of each sample were analyzed for nitrite and nitrate contents; recoveries in the spiked samples plus the results from the standard method are in good agreement. In order to validate the accuracy of the proposed method, the results were compared with those obtained by the Griess standard method. ${ }^{12}$ The results are shown in Tables 2 to 4 . Good agreement between the two methods is found.

The new method described is significant with respect to the development of a simple manifold for simultaneous determination of traces of nitrite and nitrate in the real samples. Its simplicity and reproducibility are coupled with the high speed and safety analysis of the FIA technique.

\section{Acknowledgements}

The authors thank to the Center of Excellency in Chemistry of IUT for support of this work. 


\section{References}

1. R. Tao, J. Health Lab. Tech., 1992, 2, 67.

2. V. Staden, Anal. Chim. Acta, 1982, 138, 403.

3. A. Kojlo and E. Gorodkiewicz, Anal. Chim. Acta, 1995, 302, 283.

4. A. Cerda, R. Forteza, V. Cerda, and M. T. Oms, Anal. Chim. Acta, 1998, 371, 63.

5. G. F. Wang, M. Satake, and K. Horita, Talanta, 1998, 46, 671.

6. K. V. H. Sastry, R. P. Mondgal, J. Mohan, S. Tyagi, and G. S. Rao, Anal. Biochem., 2002, 306, 79.

7. M. J. Ahmed, C. D. Stalikas, S. M. T. Karyannis, and M. I. Karayannis, Talanta, 1996, 43, 1009.
8. A. A. Ensafi and A. Kazemzadeh, Anal. Chim. Acta, 1999 $382,15$.

9. A. A. Ensafi and A. Kazemzadeh, Anal. Chim. Acta, 2001, $442,319$.

10. K. Helrich (ed.), "Official Method of Analysis of the Association of Official Analytical Chemists", 15th ed., 1990, Association of Official Analytical Chemists, Arlington, VA.

11. A. A. Ensafi, "Novel Catalytic-Kinetic Methods Combined with FIA System for the Determination of Traces of Some Inorganic and Organic Species", PhD. Thesis, Shiraz University, 1991, Shiraz, Iran.

12. B. Krieger and F. L. Malabar, "Standard Methods of Chemical Analysis", ed. F. J. Welcher, 6th ed., 1975, Vol. 3, $1127-1130$ 